\title{
Impact of Demographics and Organizational Variables on Level of Awareness, Usage Knowledge of IPRs in Business: An Empirical Study
}

\author{
Y. Lokeswara Choudary ${ }^{1} \&$ Y. Alfred Benjamin ${ }^{2}$ \\ ${ }^{1}$ PG \& Research Department of Commerce, Government Arts College, Nandanam, Chennai, India \\ ${ }^{2}$ School of Management, SRM University, Kattankulathur, Chennai, India \\ Correspondence: Y. Lokeswara Choudary, PG \& Research Department of Commerce, Government Arts College, \\ Nandanam, Chennai-35, India. E-mail: drylcphd@gmail.com
}

\author{
Received: February 25, 2015 Accepted: March 13, 2015 Online Published: May 15, 2015 \\ doi:10.5539/ass.v11n15p335 URL: http://dx.doi.org/10.5539/ass.v11n15p335
}

\begin{abstract}
Intellectual Property gives certain exclusive rights to owners to use, sell or to hire or to franchise either in full or partially, on a variety of intangible assets, such as musical, literary, and artistic works; discoveries and inventions; and words, phrases, symbols, and designs. Common types of intellectual property include copyrights, trademarks, patents, industrial design rights and trade secrets in some jurisdictions. Intellectual property protection is the key factor for business growth and advancement in the science and technology sector. The primary aim of the present paper is to study the role of demographical and organizational variables role in the level of awareness and the usage knowledge of the employees in the associated sectors in the sample area. The results indicates that, the relationship between the demographics and organizational variables and The level of awareness, importance of IPRs and Application knowledge of the IPRs for business development is highly significant at $1 \%$ level of significance. Hence, it is concluded that the level of awareness and usage of IPRs in business has close relationship with the demographic and organizational variables in the Industry.
\end{abstract}

Keywords: post liberalization era, Demographics and level of awareness analysis, IP knowledge, IP types, IPR environment improvement, IP knowledge- problems, economic growth

\section{Introduction}

Intellectual property (IP) is a term referring to a number of distinct types of creations of the mind for which a set of exclusive rights are recognized - and the corresponding fields of law. Intellectual Property is an abstract property which empowers the owner with a limited monopolistic right. While these rights are not actually property rights, the term "Property" is used because they resemble property rights in many ways. India has a long and outstanding history in Intellectual Property Rights. But somehow the journey seems to be defensive rather than aggressive. An attempt has been made to study "Intellectual property rights environment in India - a study on the problems and prospects during post liberalization era" taking samples from eight sectors such as Pharma, Industrial designs, Bulk Chemicals, R\&D, Agri-tech, Print \& Electronic Media, Education and Traditional Medical Although many of the legal principles governing intellectual property have evolved over centuries, it was not until the 19th century that the term intellectual property began to be used, and not until the late 20th century that it became commonplace in the United States. The British Statute of Anne 1710 and the Statute of Monopolies 1623 are now seen as the origin of copyright and patent law respectively.

\section{Importance of Intellectual Property}

Intellectual property protection is the key factor for economic growth and advancement in the high technology sector. Intellectual Property Rights (IPR) has taken a status symbol of a country at this globalization phase as it becomes a strategic response for the globalization and liberalization of the economic growth of a country. It also signifies the scientific, technical and industrial development of a nation. IPR drives the industrial change and attracts foreign investment in a nation. As the time goes by and the world is experiencing a sweeping change in all the spheres of life never before, now the talk of the world, very much revolves around innovation and growth. Intellectual Property has become a yard stick in measuring the innovation and the propelling growth. IPRs are good for business, benefit the public at large and act as catalysts for technical progress. If IPRs are good, more IPRs must be better. On the other side, the developing world side thinks that, IPRs are likely to cripple the 
development of local industry and technology will harm the local population and benefit none but the developed world. Corporate takes IPR as the power that keeps the business moving forward. IPR as tool to maintain their competitive advantage; for significant collaborations; to streamline processes; drive new revenue streams; maximize their profitable investment, reduce risk; drive innovation effectively and efficiently...etc. Institutions have developed various strategies to collaborate more on the research and industries versus intellectual property rights over the decades now. Developed countries have laid the proper foundation right from the education level.

\section{IPR Status in India}

Intellectual Property India: the journey so far. India meets its international obligations while safeguarding the national interests is the beaming sentence that catches our attention when we visit the IP India site. The journey of IPR - India goes back to 1856 and from there it has seen several phases and amendments before the famous 1970, Patent Act got established. The third amendment to the Patents Act, 1970 was introduced through the Patents (Amendment) Ordinance, 2004 w.e.f. 1st January, 2005. This Ordinance was later replaced by the Patents (Amendment) Act, 2005 (Act 15 of 2005) on 4th April, 2005 which was brought into force from 1st January, 2005. The most recent annual report available from the Indian Intellectual Property Office covers the fiscal year 2012/13. In 2012-13, 43,674 patent applications were filed with $1.10 \%$ of slight increasing trend when compared to the previous year. Out of this applications 12268 were examined, 9027 were disposed off and 4126 patents were granted. The total number of patents examined shows a $11.21 \%$ increase than the previous year. At the same time 8337 design applications were filed and 7252 designs were registered during the year as compared to 6590 in 2011-12; 194216 trademark applications were filed with an increasing trend of $5.79 \%$ than the previous year. In 2012-13 year 24 GI applications were filed and 21 are granted. Although the trend is increasing in applications at the IP Office only few came from Indian entities, while very few Indian Organizations seek protection outside the country. By contrast, in China, over 60 per cent of applications come from local companies. This state of affairs is something that seems to have registered with the Indian government, which has begun to devote resources to educating Indian businesses about the benefits of intellectual property.

\section{Research Methodology}

The present study is descriptive and analytical in nature. For the purpose of the survey, Employees from the vital business sectors having close association with IPRs is chosen on the basis of simple convenient method of sample. The data is collected from the selected sample respondents using a structured questionnaire. The sample covers the employees working in the industries closely related with the intellectual property rights.

The objectives of the Research:

1. To study the demographic profile of the sample using percentage analysis.

2. To find out the role of demographic and organizational variables on awareness of IPRs and its role in the growth and development of the business.

\section{Importance of the Study}

Globalisation brings its own advantages and disadvantages. India has attained a close watch player because of her potential in the field of Pharmacy, Biotechnology, Biodiversity, Service sectors, Agricultural field...etc. If we need to garner our opportunities as a global player we have position ourselves as a strategic player and this would be possible only when we have a strong hold on our IPR regime and laws that drive IPRs keeping the socio economic development in mind.

\section{Descriptive Analysis on Sample}

Percentage analysis is one of the statistical measures used to describe the characteristics of the sample or population in totality. Descriptive analysis covers the demographic data of the sample respondents and the independent variables that are used in this study. Frequency distribution of Gender, Age groups; Department, Educational Stream, Working Sector, Exposure towards IPR Environment, Source of Knowledge for IPR Information, level of Knowledge on IPRs and its implications to development, when the sample respondents came to know about IPRs and its importance and No of Years Experience in IPR Field are discussed along with bar diagram representation.

From the above table, $61.5 \%$ of the sample belongs to Male and $38.5 \%$ of sample belongs to Female. Compare to females, males are higher in representation. It is understood that males are in more in the IP related work environment. 
Table 1. Frequency distribution of sample based on the gender

\begin{tabular}{lll}
\hline Gender & Frequency & Percentage \\
\hline Male & 286 & 61.5 \\
Female & 179 & 38.5 \\
Total & 465 & 100 \\
\hline
\end{tabular}

Table 2. Frequency distribution of age group among the sample

\begin{tabular}{ccc}
\hline Age Group in years & Frequency & Percentage \\
\hline Below 30 & 228 & 49.0 \\
$31-40$ & 101 & 21.7 \\
$41-50$ & 82 & 17.6 \\
Above 50 & 54 & 11.6 \\
Total & 465 & 100.0 \\
\hline
\end{tabular}

From the above table, it is observed from the table that 228 sample respondents of below 30 years; 101 sample respondents in the range of 31 to 40 years; 82 in the group of 41 to 50 years and 54 sample respondents above 50 years have participated in this study. It is observed from the table that lot of participation are from the current working generation.

Table 3. Frequency distribution of Education Stream among the sample

\begin{tabular}{ccc}
\hline Education stream & Frequency & Percentage \\
\hline Arts & 53 & 11.4 \\
Science & 117 & 25.2 \\
Engineering & 178 & 38.3 \\
Management & 84 & 18.1 \\
Medical & 33 & 7.1 \\
Total & 465 & 100 \\
\hline
\end{tabular}

This table shows the frequency distribution of education stream among the samples. 53 sample respondents from arts stream representing $11.4 \%$ of the total sample; 117 sample respondents from science background representing $25.2 \%$ of the total sample; 178 sample respondents from engineering stream representing $38.3 \%$ of the total sample; 84 sample respondents from management stream representing $18.1 \%$ of the total sample; 33 sample respondents from Medical stream representing $7.1 \%$ of the total sample have participated in this study. Majority of the respondents were from Engineering and Science stream.

Table 4. Frequency distribution of Working Sector among the sample

\begin{tabular}{ccc}
\hline Working Sector & Frequency & Percentage \\
\hline Pharma & 30 & 6.5 \\
Industrial designs & 107 & 23.0 \\
Bulk Chemicals & 51 & 11.0 \\
R\&D & 136 & 29.2 \\
Agri-tech & 6 & 1.3 \\
Print \& Electronic Media & 22 & 4.7 \\
Education & 90 & 19.4 \\
Traditional Medical Therapy & 23 & 4.9 \\
Total & 465 & 100 \\
\hline
\end{tabular}

Form the above table it is observed from the table that 30 sample respondents from Pharma sector contributing $6.5 \%$; 107 sample respondents from industrial designs contributing 23\%; 51 from Bulk chemicals contributing to $11 \%$; 136 from R\&D contributing 29.2\%; 6 from Agritech contributing 1.3\%; 22 from printing \& electronic media contributing 4.7\%; 90 from Education contributing 19.4\%; 23 from Traditional Medical Therapy contributing $4.9 \%$ for this study. Major contributing sectors are R\&D; Industrial designs and Education whereas Agritech has contributed the lowest percentage. 
Table 5. Frequency distribution of departments among the sample

\begin{tabular}{lll}
\hline Departments & Frequency & Percentage \\
\hline Administration & 78 & 16.8 \\
Production & 195 & 41.9 \\
Research and Development & 126 & 27.1 \\
Marketing & 66 & 14.2 \\
Total & 465 & 100 \\
\hline
\end{tabular}

The table shows the frequency distribution of departments among the sample. 78 from administration contributing $16.8 \%$ to the total sample; 195 from production contributing $41.9 \%$ to the total sample; 126 from research and development contributing $27.1 \%$ to the total sample and 66 from marketing contributing $14.2 \%$ to the total sample. Marketing and administration were lowest in participation whereas production and R\&D had participated in good numbers.

Table 6. Frequency distribution of exposure towards IPR environment among the sample

\begin{tabular}{lll}
\hline Exposure & Frequency & Percentage \\
\hline Yes & 217 & 46.7 \\
No & 248 & 53.3 \\
Total & 465 & 100 \\
\hline
\end{tabular}

It is noted that $53.3 \%$ of the respondents don't have the exposure to IPR environment while the remaining $46.7 \%$ have responded positively.

Table 7. Frequency distribution of exposure towards IPR environment among the sample

\begin{tabular}{ccc}
\hline Source & Frequency & Percentage \\
\hline Friends & 173 & 37.2 \\
Relatives & 24 & 5.2 \\
News Paper & 62 & 13.3 \\
Magazine & 27 & 5.8 \\
News Letter & 12 & 2.6 \\
Handouts & 9 & 1.9 \\
Television & 6 & 1.3 \\
Exhibition & 6 & 1.3 \\
Academics & 58 & 12.5 \\
Internet-(Web) & 88 & 18.9 \\
Total & 465 & 100 \\
\hline
\end{tabular}

It is inferred that the major source of knowledge is the word of mouth by friends giving $37.2 \%$ from the total sample. Next stands the power of internet sharing $18.9 \%$ followed by newspaper $13.3 \%$ and then academics at $12.5 \%$. 24 persons have responded as relatives and thus contributing to $5.2 \% ; 27$ persons have responded as magazines and thus contributing to $5.8 \% ; 12$ persons have responded as news letter and thus contributing to $2.6 \%$; 9 persons have responded as handouts and thus contributing to $1.9 \%$ and 6 persons have responded as television and exhibition thus contributing to $1.3 \%$ for the frequency distribution of source of knowledge among the samples.

Table 8. Frequency distribution of level of knowledge on IPRs and the implications to development among the sample

\begin{tabular}{lll}
\hline Level & Frequency & Percentage \\
\hline Poor & 35 & 7.5 \\
Average & 86 & 18.5 \\
Good & 127 & 27.3 \\
V.Good & 154 & 33.1 \\
Excellent & 63 & 13.5 \\
Total & 465 & 100 \\
\hline
\end{tabular}


This table shows that $32.5 \%$ of the samples have very good level of knowledge on IPRs and implications to development among the total sample. 105 samples have responded good and 104 samples have responded average contributing $22.4 \%$ and $22.6 \%$ respectively. Interestingly $14.2 \%$ have responded excellent whereas $8.4 \%$ has poor.

Table 9. Frequency distribution of know about IPRs and its importance among the sample

\begin{tabular}{lll}
\hline Level & Frequency & Percentage \\
\hline College Level & 170 & 36.6 \\
University Level & 21 & 4.5 \\
Research Level & 62 & 13.3 \\
Career entry level & 175 & 37.6 \\
Senior employment level & 37 & 8.0 \\
Total & 465 & 100 \\
\hline
\end{tabular}

$37.6 \%$ of the sample respondents have known IPRs and its importance at career entry level; $36.6 \%$ in their college level; $13.3 \%$ at their research level and $4.5 \%$ at their university level. Surprisingly $8 \%$ have responded that they have known IPRs and its importance only at senior employment level.

Table 10. Frequency distribution of know about IPRs and its importance among the sample

\begin{tabular}{ccc}
\hline Experience & Frequency & Percentage \\
\hline Below 5 & 214 & 46 \\
$5-10$ & 130 & 28 \\
$10-15$ & 54 & 11.6 \\
Above 15 & 67 & 14.4 \\
Total & 465 & 100 \\
\hline
\end{tabular}

The data in this table shows that the majority of the respondents are in the budding stage of their years of experience as 214 persons i.e. $46 \%$ have responded less than 5 years which is the lowest data point in this category; 130 persons i.e $28 \%$ in5-10 years category; 54 sample respondents i.e $11.6 \%$ in $10-15$ years category and 67 sample respondents i.e $14.4 \%$ in above 15 years category.

\section{Inferential Analysis on Sample}

Null Hypothesis: There is no significant difference between male and female with respect to the dimensions of IPR.

Table 11. $\mathrm{t}$ test for significant difference between male and female with respect to the dimensions of IPR

\begin{tabular}{lllllll}
\hline Dimensions of IPRs Climate & Gender & $\mathrm{N}$ & Mean & Std. Deviation & t- Value & P- Value \\
\hline Knowledge on IPR used in the industry & Male & 286 & 31.65 & 13.044 & & \\
& Female & 179 & $\mathbf{3 9 . 8 0}$ & 14.431 & 6.289 & $0.000^{* *}$ \\
Problems with regard to IPR & Male & 286 & 64.71 & 12.506 & & \\
& Female & 179 & $\mathbf{7 0 . 0 2}$ & 10.341 & 4.759 & $0.000^{* *}$ \\
Importance of IPR & Male & 286 & 37.33 & 7.213 & & \\
& Female & 179 & $\mathbf{4 1 . 6 9}$ & 5.092 & 7.063 & $0.000^{* *}$ \\
\hline
\end{tabular}

Note: $* *$ Denotes significant at $1 \%$ level

Since $\mathrm{P}$ value is less than 0.01 , the null hypothesis "There is no significant difference between male and female with respect to the dimensions of IPR" is rejected at 1 percent level of significance. Hence concluded that there is significant difference between male and female with respect to the dimensions of IPR. Mean level of knowledge on IPR used in the industry is 39.80 for females and for males it is 31.65 ; problems with regard to IPR is 70.02 for females and 64.71 for males; Importance of IPR is 41.69 for females and 37.33 for males and Suggestions to improve the IPR awareness is 84.67 for females and 76.60 for males. The ANOVA test shows that there is a greater significance for female respondents than male respondents towards the dimensions of IPR.

Null Hypothesis: There is no significant difference between age groups with respect to dimensions of IPR 
Table 12. ANOVA for significant difference between age groups with respect dimensions of IPR

\begin{tabular}{llllllll}
\hline \multirow{2}{*}{ Dimensions of IPRs Climate } & \multicolumn{7}{c}{ Age Group in years } \\
& & Below 30 & $31-40$ & $41-50$ & Above 50 & F & Sig. \\
\hline \multirow{2}{*}{ Knowledge on IPR used in the industry } & Mean & $\mathbf{3 8}$ & 37 & $28 \mathrm{a}$ & 29 & \multirow{2}{*}{16.530} & \\
& SD & 14.32 & 12.26 & 11.75 & 14.46 & & \\
\multirow{2}{*}{ Problems with regard to IPR } & Mean & $\mathbf{6 9}$ & 67 & $63 \mathrm{ab}$ & 62 & & \\
& SD & 11.03 & 9.66 & 13.14 & 14.87 & 9.920 & \multirow{2}{*}{$0.000^{* *}$} \\
\multirow{2}{*}{ Importance of IPR } & Mean & $\mathbf{4 1}$ & 40 & 36 & 33 & \multirow{2}{*}{28.238} & \\
& SD & 5.62 & 4.62 & 7.15 & 9.47 & & $0.000^{* *}$ \\
\hline
\end{tabular}

1. ** Denotes significant at $1 \%$ level; 2 . Different alphabet between years of customer denotes significant at $5 \%$ level using Duncan Multiple Range test

Since $\mathrm{P}$ value is less than 0.01 , the null hypothesis "There is no significant difference between age groups with respect to dimensions of IPR" is rejected at 1 percent level of significance. Hence it is concluded that there is significant difference between age groups with respect to dimensions of IPR. Based on Duncan Multiple Range test, the below 30 years of age has a significantly higher level of knowledge on the IPR used in the industry; awareness of the problems with regard to IPR; importance of IPR and also acknowledgement for the suggestions to improve the IPR awareness than the other age groups of the sample respondents.

Null Hypothesis: There is no relationship between education stream and the dimensions of IPR

Table 13. Chi-square test for relationship between education stream and the dimensions of IPR

\begin{tabular}{|c|c|c|c|c|c|c|c|c|}
\hline \multirow{2}{*}{ Dimensions of IPRs Climate } & & \multicolumn{7}{|c|}{ Education stream } \\
\hline & & A & $\mathrm{S}$ & Eng & Mgt & $\mathrm{M}$ & $\mathrm{F}$ & Sig. \\
\hline \multirow[b]{2}{*}{ Knowledge on IPR used in the industry } & Mean & 29 & 38 & 36 & 33 & 30 & \multirow[b]{2}{*}{5.287} & \\
\hline & SD & 12.46 & 13.42 & 14.51 & 15.55 & 8.87 & & $0.000^{* *}$ \\
\hline \multirow{2}{*}{ Problems with regard to IPR } & Mean & 64 & 69 & 67 & 62 & 70 & \multirow{2}{*}{5.604} & \\
\hline & SD & 14.88 & 10.57 & 11.59 & 13.16 & 5.56 & & $0.000 * *$ \\
\hline \multirow{2}{*}{ Importance of IPR } & Mean & 36 & 41 & 39 & 37 & 40 & \multirow{2}{*}{7.495} & \\
\hline & $\mathrm{SD}$ & 8.18 & 5.66 & 6.79 & 7.35 & 3.41 & & $0.000 * *$ \\
\hline
\end{tabular}

** Denotes significant at 1\% level M- Medical; Mgt-Management; Eng-Engineering; S- Science; A-Arts

Since $\mathrm{P}$ value is less than 0.01 , the null hypothesis "There is no relationship between education stream and the dimensions of IPR" is rejected at 1 percent level of significance. Hence concluded that there is a relationship between education stream and the dimensions of IPR. Based on the above table it is inferred that Science stream has a higher level of relationship for Knowledge on IPR used in the industry (Mean: 38); Importance of IPR (Mean: 41) and Suggestions to improve the IPR awareness (Mean: 83) when compared to the other streams. Distinctly for problems with regard to IPR (Mean: 70) the medical stream has a higher level of relationship when compared to the other streams.

Null Hypothesis: There is no relationship between working sector and the dimensions of IPR

Table 14. Anova test for relationship between working sector and the dimensions of IPR

\begin{tabular}{|c|c|c|c|c|c|c|c|c|c|c|c|}
\hline \multirow{2}{*}{\multicolumn{2}{|c|}{ Dimensions of IPRs Climate }} & \multicolumn{10}{|c|}{ Working sector } \\
\hline & & 1 & 2 & 3 & 4 & 5 & 6 & 7 & 8 & $\mathrm{~F}$ & Sig. \\
\hline \multirow{4}{*}{$\begin{array}{l}\text { Knowledge on IPR } \\
\text { used in the industry } \\
\text { Problems with regard } \\
\text { to IPR }\end{array}$} & Mean & 33 & 34 & 40 & 40 & 30 & 31 & 28 & 32 & \multirow{2}{*}{8.262} & \multirow{2}{*}{$0.000^{* *}$} \\
\hline & SD & 5.87 & 14.27 & 13.66 & 14.82 & 9.31 & 13.2 & 13.03 & 8.83 & & \\
\hline & Mean & 65 & 65 & 67 & 72 & 59 & 65 & 63 & 69 & \multirow{2}{*}{5.859} & \multirow{2}{*}{$0.000^{* *}$} \\
\hline & SD & 4.73 & 11.51 & 12.24 & 11.23 & 10.95 & 14.5 & 13.32 & 7.34 & & \\
\hline \multirow{2}{*}{ Importance of IPR } & Mean & 42 & 38 & 37 & 42 & 37 & 36 & 36 & 39 & \multirow{2}{*}{11.17} & \multirow{2}{*}{$0.000 * *$} \\
\hline & SD & 2.17 & 7.14 & 4.65 & 5.43 & 3.83 & 8.33 & 7.86 & 5.84 & & \\
\hline
\end{tabular}

** Denotes significant at $1 \%$ level

1. Pharma; 2. Industrial designs; 3. Bulk Chemicals; 4. R\&D; 5. Agri-tech; 6. Print \& Electronic Media; 7. Education; 8. Traditional Medical Therapy 
Since $\mathrm{P}$ value is less than 0.01 , the null hypothesis "There is no relationship between working sector and the dimensions of IPR" is rejected at 1 percent level of significance. Hence concluded that there is a relationship between working sector and the dimensions of IPR. Based on the above table it is inferred that Bulk chemicals and R\&D with a mean value of 40 shows that they have a higher level of relationship for Knowledge on IPR used in the industry when compared to the other working sector. For importance of IPR, R\&D and Pharma with a mean value of 42 stand out of the other sectors and for suggestions to improve the IPR awareness Pharma exhibits a higher relationship with a mean value of 89 when compared to the other working sectors. Distinctly for problems with regard to IPR the R\&D sector with a mean value of 72 shows a higher level of relationship when compared to the other streams.

Null Hypothesis: There is no relationship between department and the dimensions of IPR

Table 15. ANOVA test for relationship between department and the dimensions of IPR

\begin{tabular}{llllllll}
\hline \multirow{2}{*}{ Dimensions of IPRs Climate } & \multicolumn{7}{c}{ Department } \\
& & Admn & Prod & R\&D & Mktg & F & Sig. \\
\hline \multirow{2}{*}{ Knowledge on IPR used in the industry } & Mean & 32 & 35 & $\mathbf{3 9}$ & 29 & \multirow{2}{*}{8.98} & \multirow{2}{*}{$0.000^{* *}$} \\
& SD & 14.49 & 13.12 & 15.4 & 11.48 & & \\
\multirow{2}{*}{ Problems with regard to IPR } & Mean & 66 & 67 & $\mathbf{7 1}$ & 61 & 11.04 & $0.000^{* *}$ \\
& SD & 11.12 & 11.49 & 11.23 & 13.21 & & \\
\multirow{2}{*}{ Importance of IPR } & Mean & 38 & 39 & $\mathbf{4 1}$ & 35 & 12.46 & $0.000^{* *}$ \\
& SD & 7.02 & 6.31 & 5.71 & 8.16 & & \\
\hline
\end{tabular}

** Denotes significant at 1\% level; Admn - Administration; Prod - Production; R\&D - Research and Development; Mktg - Marketing

Since $\mathrm{P}$ value is less than 0.01 , the null hypothesis "There is no relationship between department and the dimensions of IPR" is rejected at 1 percent level of significance. Hence, it is concluded that there is a relationship between department and the dimensions of IPR. Based on the above table it is inferred that R\&D has a higher level of relationship for Knowledge on IPR used in the industry; Importance of IPR; Suggestions to improve the IPR awareness and problems with regard to IPR with the mean value of 39, 71, 41 and 83 respectively when compared to the other streams. Marketing department takes the lowest mean data indicating that it has a lower level of relationship than the other departments.

Null Hypothesis: There is no relationship between no. of years of experience in the IPR field and the dimensions of IPR.

Table 16. ANOVA test for relationship between no. of years of experience in the IPR field and the dimensions of IPR

\begin{tabular}{|c|c|c|c|c|c|c|c|}
\hline \multirow{2}{*}{\multicolumn{2}{|c|}{ Dimensions of IPRs Climate }} & \multicolumn{6}{|c|}{ No of years experience in IPR field } \\
\hline & & Below 5 & $5^{\prime}-10$ & $10^{\prime}-15$ & Above 15 & $\mathrm{~F}$ & Sig. \\
\hline \multirow{2}{*}{$\begin{array}{l}\text { Knowledge on IPR } \\
\text { used in the industry }\end{array}$} & Mean & 32 & 32 & 34 & 49 & \multirow{2}{*}{30.724} & \multirow{2}{*}{$0.000^{* *}$} \\
\hline & SD & 12.13 & 14.08 & 11.47 & 14.31 & & \\
\hline \multirow{2}{*}{$\begin{array}{l}\text { Problems } \\
\text { regard to IPR }\end{array}$} & Mean & 66 & 66 & 64 & 74 & \multirow{2}{*}{9.531} & \multirow{2}{*}{$0.000 * *$} \\
\hline & SD & 11.4 & 12.54 & 9.18 & 12.55 & & \\
\hline \multirow{2}{*}{ Importance of IPR } & Mean & 38 & 40 & 38 & 42 & \multirow{2}{*}{6.867} & \multirow{2}{*}{$0.000^{* *}$} \\
\hline & SD & 7 & 6.94 & 4.58 & 6.6 & & \\
\hline
\end{tabular}

Since $\mathrm{P}$ value is less than 0.01 , the null hypothesis "There is no relationship between no. of years of experience in the IPR field and the dimensions of IPR" is rejected at 1 percent level of significance. Hence concluded that there is a relationship between no. of years of experience and the dimensions of IPR. Based on the above table it is inferred that respondents with 15 years and above experience in the IPR field has a higher level of relationship for Knowledge on IPR used in the industry; Importance of IPR; Suggestions to improve the IPR awareness and problems with regard to IPR with the mean value of 49,74, 42 and 86 respectively when compared to the other experience groups. Knowledge on IPR used in the industry has a linear relationship with the years of experience.

\section{Summary and Conclusion}

It is observed from the analysis that the low level of conceptual and practical awareness is found among the employees in the sample. The degree of awareness is found high among the engineering and science graduates 
when compared to others in the sample. The primary source of knowledge on IPRs is observed from the Friends when compared to other sources. The level of awareness, importance of IPRs and Application knowledge of the IPRs for business development and gender has highly significant relationship in the study. Similarly the relationship between the level of awareness, importance of IPRs and Application knowledge of the IPRs for business development and age and education stream is found highly significant at $1 \%$ level of significance. Hence, it is concluded that the demographical variables role in The level of awareness, importance of IPRs and Application knowledge of the IPRs for business development is indispensable. The organizational variables like, working sector, department of working and the Department of working and relating wit IPRs role on The level of awareness, importance of IPRs and Application knowledge of the IPRs for business development is also found significant at $1 \%$ level of significance. This also indicates that the role of organizational variables in The level of awareness, importance of IPRs and Application knowledge of the IPRs for business development is vital. Hence, it is concluded that the level of awareness and usage of IPRs in business has close relationship with the demographic and organizational variables in the Industry.

\section{References}

Annual Reports of office of CGPDTM. (2012-13). Retrieved from http://ipindia.gov.in/cgpdtm/AnnualReport English_2012_2013.pdf

Brad, S., \& Bently, L. (1999). The making of modern intellectual property law: the British experience, 1760-1911. Cambridge University Press.

Lemley, M. A. (2005). Property as a common descriptor of the field probably traces to the foundation of the World Intellectual Property Organization (WIPO) by the United Nations. In Property, Intellectual Property, and Free Riding. Texas Law Review, 83(1031), 1033.

Levine, D., \& Boldrin, M. (2008). Against intellectual monopoly. Cambridge University Press.

Lo, S.-T. (2004). Stregthening (sic) Intellectual Property Rights: Experience from the 1986 Taiwanese Patent Reforms. UCLA, Dept. of Economics 2004.

Raysman, R., Pisacreta, E. A., \&. Adler, K. A. (1999-2008). Intellectual Property Licensing: Forms and Analysis. Law Journal Press.

Rebecque, B. de C. de. Collection complète des ouvrages publiés sur le gouvernement représentatif et la constitution actuelle de la France: formant une espèce de cours de politique constitutionnelle (1818, p. 296).

\section{Copyrights}

Copyright for this article is retained by the author(s), with first publication rights granted to the journal.

This is an open-access article distributed under the terms and conditions of the Creative Commons Attribution license (http://creativecommons.org/licenses/by/3.0/). 